\title{
ОБЛІКОВО-АНАЛІТИЧНИЙ ІНСТРУМЕНТАРІЙ УПРАВЛІННЯ ОБОРОТНИМ КАПІТАЛОМ ПІДПРИЕМСТВ В УМОВАХ ГЛОБАЛЬНИХ ВИКЛИКІВ
}

\author{
DOI: $10.32620 /$ cher.2021.4.08
}

Постановка проблеми. Глобальні виклики спричиняють багато соціально-економічних трансформацій в діяльності суб'єктів господарювання, особливо пов'язаних з оборотними активами, зокрема перебої з постачанням виробничих запасів, зростання обсягів дебіторської заборгованості внаслідок порушення платіжної дисципліни контрагентів у зв'язку зі зниженням обсягів реалізації їх власної продукції під час карантинних заходів, зниженням платоспроможності споживачів, знеціненням фіатних грошей тощо, що спричиняє неможливість своєчасно погасити заборгованість, а зростання дебіторської заборгованості призводить до неможливості погасити власну кредиторську заборгованість. Метою статті $\epsilon$ удосконалення методики і організації обліку, аналізу і аудиту оборотних активів підприємства в умовах глобальних викликів. Предмет дослідження - процес формування та використання оборотних активів ПрАТ «ФЕД». Методи, використані в дослідженні: спостереження, порівняння, аналізу, узагальнення та формалізації, нормування, прогнозування. Гіпотеза дослідження: удосконалення процесу обліку, аналізу і внутрішнього аудиту оборотних активів дозволить підвищити ефективність їх формування і використання. Виклад основного матеріалу. Для підвищення ефективності процесу формування і використання оборотних активів в умовах глобальних викликів розроблено концептуальний підхід до їх обліку і аналізу. Здійснено прогнозування вартості оборотних засобів ПрАТ «ФЕД» на наступні два роки за допомогою трендового аналізу, в результаті чого визначено, що вартість оборотних засобів буде збільшуватись. Для оптимізації формування і використання запасів реалізовано методику $\mathrm{ABC}$-аналізу, яка дає змогу точно прорахувати необхідні обсяги закупівель за різними товарними групами; виключити з номенклатури неліквідні позиції, що дозволяє вивільнити грошові кошти, заморожені у цих товарах, знизити складські витрати, підвищити оборотність запасів; забезпечити зростання обсягу продажу. Пропонується диференціація шляхів підвищення ефективності формування і використання оборотних активів в залежності від стадії операційного циклу. Запропоновано проведення внутрішнього аудиту оборотних активів, що дозволить перевірити забезпеченість підприємства оборотними активами, виконання правил і вимог їх обліку, документального оформлення, надійності інформації. Оригінальність та практичне значення дослідження: оригінальність полягає у розробці методичних принципів обліку та аналізу оборотних активів виробничого підприємства, виявленні фактів нестачі джерел власних оборотних засобів. Висновки та пропозиції, отримані в результаті дослідження, можуть бути використані у практиці виробничого підприємства ПрАТ «ФЕД» для підвищення ефективності обліку, аналізу і аудиту оборотних активів. Висновки. Запропоновані заходи сприятимуть підвищенню ефективності формування та використання оборотних активів, зокрема зменшенню дебіторської заборгованості та підвищенню якості формування запасів.

\section{Ключові слова:}

внутрішній аудит, глобальні виклики, дебіторська заборгованість, документування, запаси, оборотні активи, облік, суб'єкти господарювання, управління.

${ }^{1}$ Татар Марина Сергіївна, канд. екон. наук, докторант, доцент кафедри фінансів, обліку і оподаткування, Національний аерокосмічний університет ім. М. Є. Жуковського «Харківський авіаційний інститут», м. Харків, Україна.

Tatar Maryna, PhD in Economics, Doctoral, Associate professor of Finance, accounting and taxation Department National Aerospace University «Kharkiv Aviation Institute», Kharkiv, Ukraine.

ORCID ID: 0000-0002-1111-7103

e-mail: marina.sergeevna.tatar@gmail.com

${ }^{2}$ Мозгова Анна Олександрівна, здобувач другого освітнього рівня спеціальності «Облік і оподаткування», Національний аерокосмічний університет ім. М. Є. Жуковського «Харківський авіаційний інститут», м. Харків, Україна.

Mozghova Anna, student of the second educational level of the specialty «Accounting and Taxation», National Aerospace University «Kharkiv Aviation Institute», Kharkiv, Ukraine.

ORCID ID: 0000-0003-2360-3464

e-mail: mozgovaya.anya13021999@gmail.com 


\section{ACCOUNTING AND ANALYTICAL TOOLS OF ENTERPRISES CURRENT ASSETS MANAGEMENT IN GLOBAL CHALLENGES CONDITIONS}

Formulation of the problem. Global challenges cause many social and economic transformations in the economic entities activities, especially related to current assets, including disruptions in the inventories supply, increasing receivables due to breach of payment discipline of counterparties due to reduced sales of their own products during quarantine measures, reduced consumer solvency, devaluation of fiat money, etc., which makes it impossible to repay the debt on time, and the growth of receivables leads to the inability to repay their own accounts payable. The aim of the research is improvement the methodology and organization of accounting, analysis and audit of enterprise current assets in the face of global challenges. The subject of the research is the process of current assets formation and usage of PJSC "FED". The methods of the research: observation, comparison, analysis, generalization and formalization, rationing, forecasting. The hypothesis of the research: improving the process of accounting, analysis and internal audit of current assets will increase the efficiency of their formation and usage. The statement of basic materials. For increasing the efficiency of the process of current assets formation and usage in the context of global challenges, a conceptual approach to their accounting and analysis has been developed. The forecasting of current assets value of PJSC "FED" for the next two years was carried out with the help of trend analysis, as a result of which it was determined that the value of current assets will increase. For optimization the inventories formation and usage, the ABCanalysis has been implemented, which makes possible to accurately calculate the required volumes of purchases by different product groups; to exclude from the nomenclature illiquid positions, which makes possible to release cash frozen in these goods, reduce warehousing costs, increase inventory turnover; ensure sales growth. To improve the system of accounting for receivables at PJSC "FED" it is proposed to open six sub-accounts to account 38 "Provision for doubtful debts", as well as to improve analytical accounting by introducing groups of debtors in terms of non-repayment of receivables. Differentiation of ways to increase the efficiency of current assets formation and usage depending on the stage of the operating cycle is proposed. Also it is proposed to conduct current assets internal audit, which will verify the security of current assets, compliance with the rules and requirements of their accounting, documentation, reliability of information. The originality and practical significance of the research: originality lies in the development of methodological principles of production enterprise current assets accounting and analysis, identifying the lack of sources of own working capital. The conclusions and proposals obtained as a research results can be used in the practice of the production enterprise of PJSC "FED" to improve the efficiency of current assets accounting, analysis and audit. Conclusions. The proposed measures will help to improve the efficiency of current assets formation and usage, in particular, to reduce accounts receivable and improve the inventories formation quality.

Keywords:

internal audit, global challenges, receivables, documentation, inventories, current assets, accounting, business entities, management.

\section{УЧЕТНО-АНАЛИТИЧЕСКИЙ ИНСТРУМЕНТАРИЙ УПРАВЛЕНИЯ ОБОРОТНЫМ КАПИТАЛОМ ПРЕДПРИЯТИЙ В УСЛОВИЯХ ГЛОБАЛЬНЫХ ВЫЗОВОВ}

Постановка проблемы. Глобальные вызовы вызывают много социально-экономических трансформаций в деятельности субъектов хозяйствования, особенно связанных с оборотными активами, в частности перебои со снабжением производственных запасов, рост объемов дебиторской задолженности вследствие нарушения платежной дисциплины контрагентов в связи со снижением объемов реализации их собственной продукции во время карантинных мероприятий, снижением платежеспособности потребителей, обесценением фиатных денег и т.д., что влечет за собой невозможность своевременно погасить задолженность, а рост дебиторской задолженности приводит к невозможности погасить собственную кредиторскую задолженность. Целью статьи является усовершенствование методики и организации учета, анализа и аудита оборотных активов предприятия в условиях глобальных вызовов. Предмет исследования - процесс формирования и использования оборотных активов ЧАО «ФЭД». Meтоды, используемые в исследовании: наблюдение, сравнение, анализ, обобщение и формализация, нормирование, прогнозирование. Гипотеза исследования: усовершенствование процесса учета, анализа и внутреннего аудита оборотных активов позволит повысить эффективность их формирования и использования. Изложение основного материала. Для повышения эффективности процесса формирования и использования оборотных активов в условиях глобальных вызовов разработан концептуальный подход к их учету и анализу. Проведено прогнозирование стоимости оборотных средств ЧАО «ФЭД» на следующие два года с 
помощью трендового анализа, в результате чего определено, что стоимость оборотных средств будет увеличиваться. Для оптимизации формирования и использования запасов реализована методика $\mathrm{ABC}$-анализа, позволяющая точно просчитать необходимые объемы закупок по разным товарным группам; исключить из номенклатуры неликвидные позиции, позволяющие высвободить денежные средства, замороженные в этих товарах, снизить складские расходы, повысить оборачиваемость запасов; обеспечить рост объема продаж. Для усовершенствования системы учета дебиторской задолженности на ЧАО «ФЭД» предложено к счету 38 «Резерв сомнительных долгов» открыть шесть субсчетов, а также усовершенствование аналитического учета путем введения групп дебиторов по срокам непогашения дебиторской задолженности. Предлагается дифференциация способов повышения эффективности формирования и использования оборотных активов в зависимости от стадии операционного цикла. Предложено проведение внутреннего аудита оборотных активов, что позволит проверить обеспеченность предприятия оборотными активами, выполнение правил и требований учета, документального оформления, надежности информации. Оригинальность $u$ практическое значение исследования: оригинальность состоит в разработке методических принципов учета и анализа оборотных активов производственного предприятия, выявлении фактов нехватки источников собственных оборотных средств. Выводы и предложения, полученные в результате исследования, могут использоваться в практике производственного предприятия ЧАО «ФЭД» для повышения эффективности учета, анализа и аудита оборотных активов. Bыводы. Предложенные меры будут способствовать повышению эффективности формирования и использования оборотных активов, в частности уменьшению дебиторской задолженности и повышению качества формирования запасов.

\section{Ключевые слова:}

внутренний аудит, глобальные вызовы, дебиторская задолженность, документирование, запасы, оборотные активы, учет, субъекты хозяйствования, управление.

Постановка проблеми. Радикальні зміни, які відбуваються в економіці України та всього світу внаслідок глобальних викликів вимагають постійного вдосконалення способів формування, розподілу й використання оборотного капіталу промислових підприємств. Стан оборотного капіталу в умовах сучасних глобальних викликів відіграє важливу роль, оскільки формує вагому та найбільш мобільну частку в активах суб'єкта господарювання. Тому суб'єкти господарювання повинні забезпечувати стан своїх оборотних активів на такому рівні, щоб своєчасно, швидко i якісно реагувати на глобальні потрясіння й зміни потреб ринку під їх впливом. Раціональне формування i використання оборотних активів й їх оптимізація $є$ одним 3 основних завдань виробничого підприємства для забезпечення безперервного виробництва за умов інфляційних процесів, кризових явищ, соціально-поведінкових обмежень внаслідок пандемії, що дасть можливість виконання виробничих планів підприємства, дотримання 30бов'язань перед контрагентами, забезпечення стійкого фінансового становища й створення умов для подальшого конкурентоспроможного розвитку підприємства.

Аналіз останніх досліджень i публікацій. Значний внесок у дослідження проблеми обліку, аналізу і аудиту в системі управління оборотним капіталом зробили такі вчені: Донін С. О. [1], Кащена Н. Б. [2], Горошанська О. О. [2], Коваленко О. В. [3], Павленко О. П. [4], Бурсук Г. Ю. [4], Пархоменко О. П. [5], Савченко А. М. [6], Матвіюк А. В. [6], Тітаренко Г. Б. [7] тощо. Проте, незважаючи на велику кількість дослідницьких робіт, у сучасній теорії та практиці немає єдиної злагодженої системи обліково-аналітичного інструментарію управління оборотним капіталом, вчені по-різному виділяють класифікаційні групи оборотних активів.

Метою статті $\epsilon$ удосконалення методики і організації обліку, аналізу і аудиту оборотних активів підприємства в умовах глобальних викликів.

Виклад основного матеріалу дослідження. Глобальні виклики сучасності суттєво змінили й продовжують змінювати соціально-економічне, психологічне, інформаційне та правове середовища підприємств. Ефективність діяльності підприємства за таких умов значною мірою залежить від наявності та ефективності використання оборотних коштів.

У процесі формування, розподілу й використання оборотного капіталу підприємство взаємодіє з різними суб'єктами, які слід згрупувати за такими напрямами:

- взаємодія підприємств з банками щодо організації безготівкових розрахунків, отри- 
мання та погашення короткострокових і довгострокових кредитів, оскільки кредит є джерелом формування оборотного капіталу;

- взаємодія підприємств $з$ фондовим ринком при здійсненні операцій з емісією та розміщенням цінних паперів, від їх організації залежить можливість залучення додаткових джерел фінансування промислової діяльності;

- взаємодія стосовно формування централізованих грошових фондів та їх використання на поповнення оборотного капіталу;

- взаємодія між підприємствами та організаціями під час реалізації готової продукції й придбання матеріальних цінностей для господарської діяльності, роль цієї групи соціально-економічних відносин першорядна, оскільки саме у сфері матеріального виробництва створюється національний дохід, підприємства отримують виручку від реалізації продукції та прибуток;

- взаємодія між підрозділами промислового підприємства, пов'язана 3 розподілом оборотного капіталу між стадіями відтворювального процесу.

\section{Таблиця 1 - Показники ефективності використання оборотних активів}

\begin{tabular}{|c|c|c|c|c|c|c|c|}
\hline \multirow[b]{2}{*}{ Фінансовий показник } & \multirow{2}{*}{$\begin{array}{c}\text { Нормативне } \\
\text { значення }\end{array}$} & \multicolumn{6}{|c|}{ Значення за роками } \\
\hline & & 2016 & 2017 & 2018 & 2019 & 2020 & $\begin{array}{c}\text { Відхилення } \\
(+/-)\end{array}$ \\
\hline $\begin{array}{l}\text { 1. Коефіцієнт рентабель- } \\
\text { ності активів }\end{array}$ & Збільшення & 0,16 & 0,10 & 0,07 & 0,09 & 0,11 & $-0,05$ \\
\hline $\begin{array}{l}\text { 2. Коефіцієнт оборотності } \\
\text { активів }\end{array}$ & Збільшення & 0,71 & 0,87 & 0,90 & 0,95 & 0,80 & 0,09 \\
\hline $\begin{array}{l}\text { 3. Коефіцієнт оборотності } \\
\text { запасів }\end{array}$ & Збільшення & 0,76 & 0,85 & 0,82 & 0,77 & 0,56 & $-0,20$ \\
\hline 4. Коефіцієнт покриття & $>1$ & 4,55 & 4,09 & 2,67 & 4,18 & 4,35 & $-0,20$ \\
\hline $\begin{array}{l}\text { 5. Коефіцієнт швидкої лікві- } \\
\text { дності }\end{array}$ & $>1$ & 0,96 & 0,98 & 0,75 & 1,00 & 1,14 & 0,17 \\
\hline $\begin{array}{l}\text { 6. Коефіцієнт абсолютної } \\
\text { ліквідності }\end{array}$ & $>0,2$ & 0,18 & 0,09 & 0,17 & 0,09 & 0,13 & $-0,05$ \\
\hline
\end{tabular}

Джерело: розраховано авторами на підставі [8]

Пропонується прогнозування вартості оборотних засобів ПрАТ «ФЕД» на наступні два роки (2021-2022 рр.) за допомогою трендового аналізу, для чого застосовуються трендові криві, тобто математичні функції за допомогою яких описується основна тенденція. Аналітичне вирівнювання проводиться по прямолінійному тренду (1):

$$
Y_{t}=a_{0}+a_{1} t
$$

Для підвищення ефективності процесу формування і використання оборотних активів в умовах глобальних викликів розроблено концептуальний підхід до їх обліку і аналізу (рисунок 1).

Обсяг оборотних коштів підприємства повинен наближатися до оптимального, тобто задовольняти потреби в ньому.

Основну частину оборотних активів підприємства займають виробничі запаси та дебіторська заборгованість. 32016 по 2020 роки відбулося значне нагромадження оборотних активів, а саме збільшення запасів на 52896 тис. грн. (на 19,04 \%), дебіторської заборгованості за товари, роботи послуги на 32940 тис. грн. (на 69,03 \%). Сума дебіторської заборгованості за виданими авансами зросла на 1716 тис. грн. або на 29,01 \%, інша поточна заборгованості на 3134 тис. грн. або на 2107,04 \%, зросли витрати майбутніх періодів на 59,14 \%, інші оборотні активи на 162,21 \%. Основні показники ефективності використання оборотних активів ПрАТ «ФЕД» за 2016-2020 рр. наведено в таблиці 1. 
Основна мета - підвищення ефективності використання оборотних активів за допомогою удосконалення методики та організації обліку і аналізу оборотних активів.

Принципи: взаємопов'язаність, своєчасність, інформованість, орієнтованість на стратегічні цілі, оптимальність

Функції: планування, організація, мотивація, контроль, регулювання

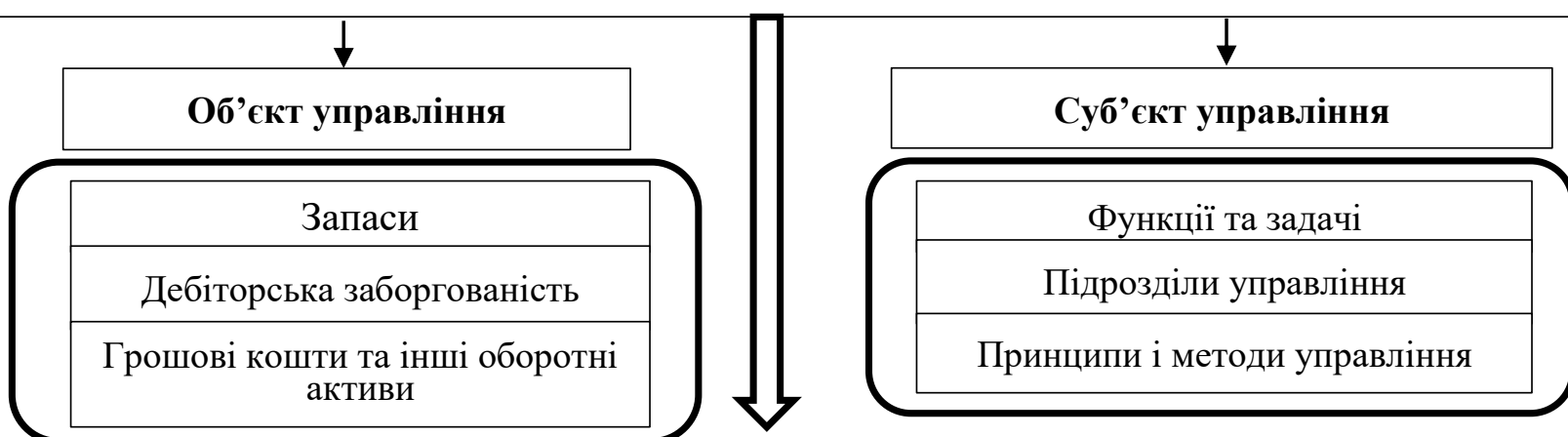

Основні завдання обліку і аналізу оборотних активів: оптимізація обсягу оборотного капіталу й забезпечення безперервного процесу виробництва.

$\mathbf{- 2}$

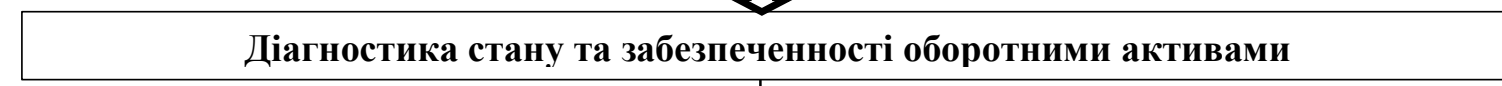

За допомогою метода коефіцієнтів розраховують показники, що характеризують стан оборотного капіталу, а також стан джерел формування оборотного капіталу та ефективність його використання.

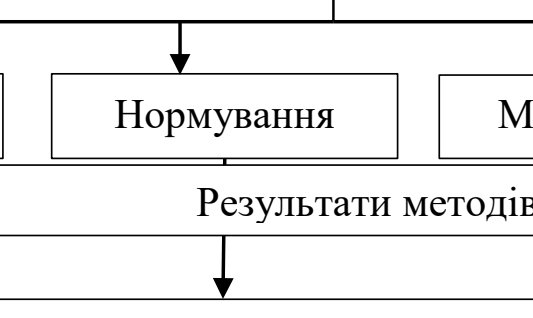

Нормування оборотних активів підприємств - це визначення потреби в оборотних коштах, що залежить від різних факторів: організації процесу виробництва, умов постачання товарно-матеріальних цінностей та умов реалізації готової продукції.

Основні етапи обліку і аналізу в системі управління оборотними активами:

1. Визначення внутрішніх і зовнішніх чинників впливу на формування і використання оборотних активів

2. Аналіз обсягу оборотних активів і його оптимізація

3. Оптимізація постійної та змінної частин оборотних активів

4. Забезпечення необхідної ліквідності оборотних активів

5. Забезпечення підвищення рентабельності оборотних активів

6. Забезпечення мінімізації втрат оборотних активів у процесі їх використання

7. Оптимізапія стпvктvnи лжепел фінансvвання обопотних активів

Результат: підвищення ефективності формування і використання оборотних активів ПАТ «ФЕД», а також удосконалення організації обліку і аналізу оборотних активів промислового підприємства.

Рисунок 1 - Концепція дослідження обліку і аналізу оборотного капіталу Джерело: розроблено авторами 
Таблиця 2 - Вхідні дані для трендового аналізу

\begin{tabular}{|c|c|c|c|c|c|}
\hline \multirow{2}{*}{ Показники } & \multicolumn{5}{|c|}{ Значення за роками } \\
\cline { 2 - 6 } & 2016 & 2017 & 2018 & 2019 & 2020 \\
\hline $\mathrm{t}$ & 1 & 2 & 3 & 4 & 5 \\
\hline $\begin{array}{c}\mathrm{y}(\mathrm{t})-\text { сума оборотних } \\
\text { активів, тис. грн. }\end{array}$ & 352402 & 372408 & 449635 & 398375 & 447565 \\
\hline
\end{tabular}

Джерело: розраховано авторами на підставі [8]

Таблиця 3 - Результати розрахунків

\begin{tabular}{|c|c|c|c|c|c|c|}
\hline \multirow{2}{*}{ Рік } & \multirow{2}{*}{$\begin{array}{c}\text { Вартість основ- } \\
\text { них засобів тис., } \\
\text { у }\end{array}$} & \multicolumn{5}{|c|}{ Розрахункові дані } \\
\hline & & $\mathrm{t}$ & $\mathrm{t} 2$ & $\mathrm{yt}$ & $\mathrm{yt}$ & yi-yt \\
\hline 2016 & 352402 & 1 & 1 & 352402 & 361033,64 & -8632 \\
\hline 2017 & 372408 & 2 & 4 & 744816 & 382555,32 & -10147 \\
\hline 2018 & 449635 & 3 & 9 & 1348905 & 404077 & 45558 \\
\hline 2019 & 398375 & 4 & 16 & 1593500 & 425598,68 & -27224 \\
\hline 2020 & 447565 & 5 & 25 & 2237825 & 447120,36 & 445 \\
\hline$\sum$ & 2020385 & 15 & 55 & 6277448 & 2020385 & \\
\hline
\end{tabular}

Джерело: розраховано авторами на підставі [8]

$$
\left\{\begin{array}{c}
\sum_{y}=a_{0} n+a_{1} \sum t \\
\sum_{y t}=a_{0} \sum t+a_{1} \sum t^{2}
\end{array},\right.
$$

де $\mathrm{n}$ - кількість років

$$
\begin{gathered}
\left\{\begin{array}{c}
2020385=a_{0} 5+a_{1} 15 \\
6277448=a_{0} 15+a_{1} 55
\end{array}\right. \\
\left\{\begin{array}{c}
404077=a_{0}+a_{1} 3 \\
418496,53=a_{0}+a_{1} 3,67
\end{array}\right.
\end{gathered}
$$

Надалі рівняння має такий вигляд:

$$
14419,53=a_{1} 0,67
$$
потрібно:

Для того, щоб знайти невідомі змінні

$$
a_{1}=\frac{14419,53}{0,67}=21521,68
$$

$$
\begin{aligned}
a_{0}= & 404077-21521,68 \times 3=339511,96 \\
& Y_{t}=339511,96+21521,68 \times t \\
& \text { Провівши відповідні розрахунки отри- }
\end{aligned}
$$
маємо, що середньорічна вартість оборотних фондів збільшиться на 21521,68 тис. грн.

Отже, отриманий прогноз на 2021 та 2022 роки:

$$
\begin{gathered}
Y_{t(2021)}=339511,96+21521,68 \times 6 \\
=468642 \\
Y_{t(2021)}=339511,96+21521,68 \times 7 \\
=490163,7
\end{gathered}
$$

У результаті трендового аналізу можна зробити висновок, що вартість оборотних засобів на наступні два роки буде збільшуватись, у 2021 році вони становитимуть 468642 тис. грн, а в $2022-490163,7$ тис. грн. (таблиця 4).

Таблиця 4 - Прогнозні значення показників

\begin{tabular}{|l|c|c|c|}
\hline \multicolumn{1}{|c|}{ Показники } & 2020 p. & $\begin{array}{c}\text { Прогнозне } \\
\text { значення }\end{array}$ & Відхилення, +/- \\
\hline 1. Середньорічна вартість оборотних коштів, тис. грн & 447565 & 468642 & 21077 \\
\hline 2. Сума обороту, тис. грн & 454915 & 541240 & 86325 \\
\hline 3. Коефіцієнт оборотності оборотних засобів & 1,02 & 1,15 & 0,14 \\
\hline 4. Тривалість обороту оборотних коштів, днів & 354 & 312 & -42 \\
\hline 5. Коефіцієнт закріплення оборотних засобів & 0,98 & 0,87 & $-0,12$ \\
\hline 6. Одноденний оборот звітного року, тис.грн & 1263,65 & 1503,44 & 239,79 \\
\hline $\begin{array}{l}\text { 7. Вилучено обігу (-),залучено до обігу (+) оборотних } \\
\text { коштів в результаті сповільнення,прискорення оборо- } \\
\text { тів порівняно з базисним роком }\end{array}$ & -63853 & \\
\hline
\end{tabular}


Коефіцієнт оборотності оборотних коштів збільшиться на 0,14 рази, тривалість обороту прискориться на 42 дні, що дозволить збільшити використання коштів на формування оборотних активів в сумі 63853 тис. грн.

В складі виробничих запасів на ПрАТ «ФЕД» нормуються наступні групи оборотних активів - сировина, основні матеріали, покупні напівфабрикати, паливо, тара, запасні частини, малоцінні та швидкозношувані предмети. Для оптимізації формування і використання запасів пропонується використання методу $\mathrm{ABC}$, що полягає у групуванні позицій товарного асортименту виробництва за ступенем їхнього впливу на загальній обсяг продажу (таблиця 5). Результати $\mathrm{ABC}$-аналізу наведено в таблиці 6.

\section{Таблиця 5 - Групування товарів в групи за результатами АВС-аналізу}

\begin{tabular}{|c|c|c|l|}
\hline Група & $\begin{array}{c}\text { Частка групи в } \\
\text { сумарному то- } \\
\text { варообігу }\end{array}$ & $\begin{array}{c}\text { Кумулятивна } \\
\text { частка груп у } \\
\text { товарообігу }\end{array}$ & \multicolumn{1}{|}{ Характеристика товарів, які входять до групи } \\
\hline А & $50-80 \%$ & $50-80 \%$ & $\begin{array}{l}\text { Товари-лідери, які визначають комерційний та фінансовий } \\
\text { стан підприємства, ії статус на ринку; найбільш важливі }\end{array}$ \\
\hline В & $10-20 \%$ & $70-90 \%$ & $\begin{array}{l}\text { Супутні товари; товари, які нещодавно введені до асортиме- } \\
\text { нту; товари, які втратили статус лідерів; проміжні за значен- } \\
\text { ням }\end{array}$ \\
\hline С & $5-10 \%$ & $100 \%$ & $\begin{array}{l}\text { Товари, які без ризику можна вивести з асортименту; товари, } \\
\text { які щойно введені до асортименту }\end{array}$ \\
\hline
\end{tabular}

Джерело: розроблено авторами на підставі [5]

Таблиця 6 - АВС-аналіз товарної номенклатури ПрАТ «ФЕД» за 2020 р.

\begin{tabular}{|c|c|c|c|c|c|c|}
\hline Номенклатурна група & $\begin{array}{l}\text { Ціна, } \\
\text { тис. } \\
\text { грн }\end{array}$ & $\begin{array}{c}\text { Обсяг } \\
\text { продажу, } \\
\text { шт. }\end{array}$ & $\begin{array}{l}\text { Товарообіг, } \\
\text { тис. грн. }\end{array}$ & $\begin{array}{l}\text { Частка в } \\
\text { товароо- } \\
\text { бігу, \% }\end{array}$ & \multicolumn{2}{|c|}{$\begin{array}{c}\text { Кумулятивна час- } \\
\text { тка в товароо- } \\
\text { бігу, \% }\end{array}$} \\
\hline \multicolumn{7}{|c|}{ ПРОДУКЦІЯ ДЛЯ АВІАЦІЇ } \\
\hline $\begin{array}{l}\text { Гідроагрегати різного призна- } \\
\text { чення }\end{array}$ & 49580 & 480 & 23798400 & 5,25 & 5,25 & \multirow{4}{*}{ до $15 \% \mathrm{~A}$} \\
\hline Гідромотори & 42500 & 432 & 18360000 & 4,05 & 9,30 & \\
\hline $\begin{array}{l}\text { Системи енергозабезпе- } \\
\text { чення }\end{array}$ & 50000 & 65 & 3250000 & 0,72 & 10,02 & \\
\hline $\begin{array}{l}\text { Топивно-регулююче облад- } \\
\text { нання }\end{array}$ & 37530 & 452 & 16963560 & 3,74 & 13,76 & \\
\hline \multicolumn{7}{|c|}{ ПРОДУКЦІЯ ДЛЯ ЗАЛІЗНИЧНОЇ ДОРОГИ } \\
\hline Камера 295М.001 & 6271 & 299 & 1875029 & 0,41 & 0,41 & \multirow{5}{*}{$\begin{array}{c}5 \% \\
\mathrm{~B}\end{array}$} \\
\hline $\begin{array}{l}\text { Магістральна частина } \\
483 \text { М.010 }\end{array}$ & 6800 & 320 & 2176000 & 0,48 & 0,89 & \\
\hline Головна частина 270.023-1 & 10950 & 140 & 1533000 & 0,34 & 1,23 & \\
\hline Повітряроспільник 483М & 18000 & 380 & 6840000 & 1,51 & 2,74 & \\
\hline Авторежим 265A-1M & 2500 & 599 & 1497500 & 0,33 & 3,07 & \\
\hline \multicolumn{7}{|c|}{ ПРОДУКЦІЯ ДЛЯ БРОНЕТЕХНІКИ } \\
\hline Електропневмоклапан ЕК-48 & 898 & 131 & 117638 & 0,03 & 0,03 & \multirow{9}{*}{$85 \% \mathrm{C}$} \\
\hline $\begin{array}{l}\text { Электропневмоклапан } \\
\text { ЭПК-69 }\end{array}$ & 4000 & 150 & 600000 & 0,13 & 0,16 & \\
\hline Привод вертикали ПВ1888 & 1960 & 170 & 333200 & 0,07 & 0,23 & \\
\hline $\begin{array}{l}\text { Комплексная система управ- } \\
\text { ления движением танка }\end{array}$ & 48950 & 50 & 2447500 & 0,54 & 0,77 & \\
\hline Інструмент & 3260 & 2500 & 8150000 & 1,80 & 2,57 & \\
\hline Прес-форми & 41200 & 2600 & 107120000 & 23,63 & 26,20 & \\
\hline $\begin{array}{l}\text { Послуги з гальванічних, тер- } \\
\text { мічних робіт, механообробка }\end{array}$ & 3000 & 2300 & 6900000 & 1,52 & 27,72 & \\
\hline Деталі розсипом & 5600 & 10000 & 56000000 & 12,35 & 40,07 & \\
\hline Ремонт агрегатів & 28900 & 6815 & 196953500 & 43,44 & 83,51 & \\
\hline
\end{tabular}


Ефектом АВС-аналізу є можливість точно визначити необхідні обсяги закупівель за різними товарними групами; виключити з номенклатури неліквідні позиції, що дозволяє вивільнити грошові кошти, заморожені у цих товарах, знизити складські витрати, підвищити оборотність запасів.
На підставі проведеного вище аналізу встановлено, що на ПАТ «ФЕД» дебіторська заборгованість займає понад $20 \%$ в оборотних активах, що негативно впливає на платоспроможність, тому запропоновано шляхи удосконалення системи ії обліку (рисунок 2).

\begin{tabular}{|c|c|}
\hline \multicolumn{2}{|r|}{ Шляхи удосконалення системи обліку розрахунків із покупцями і замовниками } \\
\hline & $\begin{array}{c}\text { Збільшення кількості покупців і замовників підприємства, що дасть змогу } \\
\text { мінімізувати ризик несплати заборгованості }\end{array}$ \\
\hline & $\begin{array}{l}\text { Моніторинг дебіторів підприємства, оцінка їх фінансового стану та плато- } \\
\text { спроможності }\end{array}$ \\
\hline & $\begin{array}{c}\text { Створити резерв сумнівних боргів та виробити порядок його визначення в } \\
\text { обліковій політиці підприємства }\end{array}$ \\
\hline & $\begin{array}{c}\text { Своєчасно здійснювати контроль співвідношення дебіторської та кредитор- } \\
\text { ської заборгованості }\end{array}$ \\
\hline & $\begin{array}{c}\text { Управління при лімітуванні дебіторської заборгованості як у загальних об- } \\
\text { сягах, так і в розрахунку на одного дебітора (існуючого чи потенціального) } \\
\text { і періодично переглядати граничні суми }\end{array}$ \\
\hline & Систематично проводити інвентаризацію заборгованості \\
\hline
\end{tabular}

Рисунок 2 - Шляхи удосконалення обліку дебіторської заборгованості Джерело: складено авторами на підставі $[2,3]$

Для удосконалення системи обліку дебіторської заборгованості на ПрАТ «ФЕД», пропонується до рахунка 38 «Резерв сумнівних боргів» відкрити шість субрахунків (рисунок $3)$.

\begin{tabular}{|l|c|}
\hline Субрахунок 382 «Розрахунки з дебіторами від 1 до 3 місяців» \\
\hline Субрахунок 383 «Розрахунки з дебіторами від 3 до 6 місяців» \\
\hline Субрахунок 384 «Розрахунки 3 дебіторами від 6 до 9 місяців» \\
\hline
\end{tabular}

Рисунок 3 - Запропонована трансформація рахунка 38 «Резерв сумнівних боргів за дебіторами» для обліку дебіторської заборгованості на ПАТ «ФЕД»

Джерело: розраховано авторами 
Отже, уся дебіторська заборгованість, яка $є$ у підприємства на певну дату, буде поділена на шість групи, за кожною з таких груп підприємство має зробити вибірку за період спостереження. Усі виявлені факти простроченої заборгованості та порушення розрахункової дисципліни, а також вжиті заходи пропонується узагальнювати у спеціальній відомості (табл. 7).

Таблиця 7 - Відомість простроченої дебіторської заборгованості

\begin{tabular}{|c|c|c|c|c|c|c|c|}
\hline \multirow[b]{2}{*}{$\begin{array}{c}\text { Наймену- } \\
\text { вання дебі- } \\
\text { тора }\end{array}$} & \multirow{2}{*}{$\begin{array}{c}\text { На кі- } \\
\text { нець } \\
\text { року, } \\
\text { тис. грн. }\end{array}$} & \multicolumn{5}{|c|}{ Зокрема, за строками непогашення, тис. грн. } & \multirow[b]{2}{*}{$\begin{array}{c}\text { Вжиті заходи } \\
\text { (i/aбо) }\end{array}$} \\
\hline & & $\begin{array}{c}\text { від } 12 \\
\text { до } 18 \\
\text { місяців }\end{array}$ & $\begin{array}{c}\text { від } 18 \\
\text { до } 24 \\
\text { місяців }\end{array}$ & $\begin{array}{c}\text { від } 24 \\
\text { до } 30 \\
\text { місяців }\end{array}$ & $\begin{array}{c}\text { від } 30 \\
\text { до } 36 \\
\text { місяців }\end{array}$ & $\begin{array}{c}\text { понад } \\
36 \text { міся- } \\
\text { ців }\end{array}$ & \\
\hline$\cdots$ & & & & & & & $\begin{array}{l}\text { Психологічні, } \\
\text { економічні, юри- } \\
\text { дичні, фізичні }\end{array}$ \\
\hline $\begin{array}{l}\text { Всього на кі- } \\
\text { нець року }\end{array}$ & & & & & & & \\
\hline
\end{tabular}

Джерело: розроблено авторами

Управління заборгованістю підприємства передбачає розробку плану-графіку роботи з дебіторами щодо інкасації заборгованості, яка базується на інвентаризації заборгованості, іiі ранжуванні за строками, забезпеченості та надійності повернення. Пропонується диференціація шляхів підвищення ефективності формування і використання оборотних активів в залежності від стадії операційного циклу, а саме передвиробничої, виробничої та реалізаційну стадій.

Пропонується проведення внутрішнього аудиту оборотних активів, План проведення якого представлено в таблиці 8. Проведення внутрішнього аудиту оборотних активів до- зволить перевірити забезпеченість підприємства оборотними активами, виконання правил i вимог їх обліку, документального оформлення, надійності інформації.

Висновки та перспективи подальших досліджень. Нагальним питанням у вирішенні проблем, пов'язаних з обліком оборотних активів в умовах глобальних викликів, пов'язаних 3 порушеннями платіжної дисципліни контрагентів у зв'язку зі зниженнями обсягів реалізації їх продукції внаслідок карантинних заходів, зниження платоспроможності споживачів тощо, що спричиняє неможливість своєчасно погасити заборгованість, $\epsilon$ впровадження концепції, яка передбачає реалізацію заходів, які б забезпечили розширення

\section{Таблиця 8 - План проведення внутрішнього аудиту оборотних активів}

\begin{tabular}{|c|c|c|c|}
\hline $\begin{array}{c}\text { Етап аудиторсь- } \\
\text { кої перевірки }\end{array}$ & Зміст & $\begin{array}{c}\text { Термін } \\
\text { виконання }\end{array}$ & Виконавець \\
\hline Підготовчий & $\begin{array}{l}\text { оцінка системи внутрішнього контролю суб'єкта гос- } \\
\text { подарювання; визначення аудиторського ризику; ви- } \\
\text { значення рівня суттєвості; складання програми аудиту }\end{array}$ & $\begin{array}{c}28.08- \\
29.08 .2021\end{array}$ & Аудитор ПІБ \\
\hline Фактичний & $\begin{array}{l}\text { аналіз результатів попередніх інвентаризацій; спосте- } \\
\text { реження за ходом проведення інвентаризації; висно- } \\
\text { вки за результатами інвентаризацій }\end{array}$ & $\begin{array}{c}30.08- \\
2.09 .2021\end{array}$ & Аудитор ПІБ \\
\hline Основний & $\begin{array}{l}\text { виконання аудиторських процедур відповідно до про- } \\
\text { грами аудиту; оформлення робочих документів; кори- } \\
\text { гування аудиторського ризику, рівня суттєвості; офор- } \\
\text { млення підсумкових документів }\end{array}$ & $\begin{array}{c}3.09- \\
7.09 .2021\end{array}$ & Аудитор ПІБ \\
\hline Завершальний & $\begin{array}{l}\text { Узагальнення результатів перевірки: аналіз виявлених } \\
\text { порушень, зловживань; узгодженість виявлених пору- } \\
\text { шень з управлінським персоналом та їх виправлення; } \\
\text { складання аудиторського звіту; підписання акту нада- } \\
\text { них послуг }\end{array}$ & $\begin{array}{c}8.09- \\
9.09 .2021\end{array}$ & Аудитор ПІБ \\
\hline
\end{tabular}

Джерело: розроблено авторами на підставі [2] 
оперативних можливостей бухгалтерського обліку і внутрішнього аудиту; а також підвищення достовірності та порівнюваності облікової інформації в частині отримання зведених фактичних показників щодо оборотних активів органами статистики, податкової служби для прийняття раціональних рішень на рівні держави щодо коригування окремих нормативних актів.

\section{Література}

1. Донін Є. О. Особливості сучасних підходів щодо специфіки класифікації оборотних активів підприємства. Економіка і організація управління. 2018. № 1. С. 75-85.

2. Кащена Н. Б., Горошанська О. О. Інформаційно-аналітичне забезпечення управління оборотними активами підприємства. Економічна стратегія $і$ перспективи розвитку сфери торгівлі та послуг. 2015. Вип. 2. C. 27-39.

3. Коваленко О. В. Формування і використання оборотного капіталу підприємства: пошук шляхів підвищення ефективності. Причорноморські економічні студіi. 2019. Вип. 41. C. 203-208.

4. Павленко О. П., Бурсук Г. Ю. Фінансовий аналіз оборотних активів та оптимізація джерел їх формування. Молодий вчений. 2017. № 10. С. 981-984.

5. Пархоменко О. П. Оборотний капітал в умовах глобальних викликів: формування та використання : монографія. Луганськ :Вид-во «Ноулідж». 2012. 216 с.

6. Савченко А. М., Матвіюк А. В. Оборотні активи виробничого підприємства в сучасних умовах: обліково-аналітичний аспект. Східна Європа: економіка, бізнес та управління. 2019. Випуск 6 (23). С. 698-705.

7. Тітаренко Г. Б. Проблемні питання оцінки оборотних активів в бухгалтерському обліку. Науковий вісник Державної академії

Стаття надійшла

до редакції : 11.11.2021 p. статистики, обліку та аудиту. 2008. № 1 (18). C. 74-79.

8. Офіційний веб-сайт ПрАТ «ФЕД» URL: https://fed.ua/ru/

\section{References}

1. Donin Ye. O. (2018). Features of modern approaches to the specifics of the classification of current assets of the enterprise. Economics and organization of management, 1, 75-85.

2. Kashchena N. B., Horoshanska O. O. (2015). Information and analytical support of current assets management of the enterprise. Economic strategy and prospects for trade and services, 2, 27-39.

3. Kovalenko O. V. (2019). Formation and use of working capital of the enterprise: finding ways to increase efficiency. Black Sea Economic Studies, 41, 203-208.

4. Pavlenko O. P., Bursuk H. Yu. (2017). Financial analysis of current assets and optimization of sources of their formation. Young scientist, 10, 981-984.

5. Parkhomenko O. P. (2012). Working capital in the context of global challenges: formation and use: monograph. Luhansk: Knowledge Publishing House, 216.

6. Savchenko A. M., Matviiuk A. V. (2019). Current assets of the production enterprise in modern conditions: accounting and analytical aspect. Eastern Europe: Economy, Business and Management, 6 (23), 698-705.

7. Titarenko H. B. (2008). Problematic issues of valuation of current assets in accounting. Scientific Bulletin of the State Academy of Statistics, Accounting and Auditing, 1 (18), 7479.

8. Official website of PJSC "FED". Retrieved from: https://fed.ua/ru/

Стаття прийнята

до друку: 30.12.2021 p.

\section{Бібліографічний опис для цитування :}

Татар М. С. Обліково-аналітичний інструментарій управління оборотним капіталом підприємств в умовах глобальних викликів / М. С. Татар, А. О. Мозгова // Часопис економічних реформ. - 2021. - №4 (44). - С. 52-61. 